\section{Splatając na nowo Latoura z Foucaultem: od etnografii do archeologii laboratorium humanistycznego}

\author{
Aleksandra Kil, Jacek Małczyński, Dorota Wolska
}

Artykułpowstał w ramach grantu OPUS 13 Narodowego Centrum Nauki realizowanego w Instytucie Kulturoznawstwa UWr w latach 2018-2021 (nr UMO-2017/25/B/ HS2/o0593, kierownik projektu: Dorota Wolska).
TEKSTY DRUGIE 2021, NR 2, S. 63-83

DOI: 10.18318/td.2021.2.4 | Aleksandra Kil - ORCID: 0000-0002-9750-3901

Jacek Małczyński - ORCID: 0000-0002-3616-2103

Dorota Wolska - ORCID: 0000-0001-9851-1463
$\mathbf{Z}$ anim w 1952 roku Michel Foucault uzyskał dyplom z psychopatologii, brał udział w „demonstracjach przypadków" w paryskim Szpitalu św. Anny, uznawanym wówczas za „sanktuarium psychologii eksperymentalnej". W tym czasie zaprzyjaźnił się z Jacqueline Verdeaux, która pracowała w tamtejszym laboratorium elektroencefalograficznym. Na praktykach Foucault nie tylko pomagał w przeprowadzaniu eksperymentów, lecz także sam się nim poddawał. Rozważał nawet utworzenie własnego laboratorium psychologicznego w École Normale Supérieur. Jak pisze Didier Eribon, staż w szpitalu był dla Foucaulta formą „badań w terenie"1. Ten wczesny

1 D. Eribon Michel Foucault. Biografia, przeł. J. Levin, Wydawnictwo KR, Warszawa 2005, s. 75-77. W tym samym czasie Foucault towarzyszył również Verdeaux w testowaniu więźniów w podparyskim Fresnes. Późniejsze zainteresowanie historią szpitala i więzienia można interpretować jako echo tych „doświadczeń". W Nadzorować i karać, analizując projekt panoptikonu Jeremy'ego Benthama, Foucault pisał o "laboratorium władzy”. M. Foucault Nadzorować i karać. Narodziny więzienia, przeł. T. Komendant, Aletheia, Warszawa 1998, s. 199.
Autorzy reprezentują Laboratorium Humanistyki Współczesnej działające przy Instytucie Kulturoznawstwa Uniwersytetu Wrocławskiego od 2014 roku. Wspólnie opublikowali: Z archeologii laboratorium humanistycznego.Zwodniczy przypadek Laboratoire d'anthropologie sociale Claude'a Lévi-Straussa („Konteksty”2020, nr 3); Współmyślność. Ku laboratorium humanistycznemu (w: Nowa humanistyka. Zajmowanie pozycji, negocjowanie autonomii, red. P. Czapliński, R. Nycz i in., Warszawa 2017) oraz zredagowali Kulturę nie-ludzkq ("Prace Kulturoznawcze” 2015, nr 18). 
etap twórczości naukowej autora Słów i rzeczy bywa pomijany jako falstart, tymczasem, jak dowodzi Elisabetta Basso, ów laboratoryjny epizod zaważył na jego późniejszych zainteresowaniach².

Życie laboratoryjne. Konstruowanie faktów naukowych to praca, która uczyniła Brunona Latoura jednym z pionierów antropologii laboratorium. To właśnie ono - jako locus uprawiania nauki - naznaczyło jego dalszą karierę, stając się elementem Latourowskiej sygnatury, ważnym tematem kolejnych prac $\mathrm{i}$ istotnym wątkiem w recepcji jego dorobku. Także w Polsce Latour znany jest jako współtwórca teorii aktora-sieci, wywodzonej wprost z etnografii laboratorium³ ${ }^{3}$. Co ciekawe, polski przekład Życia laboratoryjnego ukazał się dopiero w minionym roku - długo po tym, jak studia nad nauką zwróciły się ku laboratoriom i być może nawet gdy ich gwiazda już nieco przygasła ${ }^{4}$. Może jednak to odpowiedni czas, by to pionierskie studium laboratoryjnej codzienności odnieść teraz do laboratoriów humanistycznych.

W artykule poddajemy refleksji metodologiczny aspekt projektu „Laboratorium humanistyczne jako modus poznania”'. Chcemy pokazać, dlaczego

2 E. Basso Foucault's critique of the human sciences in the 1950s: between psychology and philosophy, "Theory, Culture \& Society" November 2020.

3 Pierwsze prezentacje twórczości Latoura w Polsce ukazały się na początku XXI wieku m.in. na łamach "Tekstów Drugich". Zob. E. Bińczyk "Antropologia nauki” Bruno Latoura na tle polemik, "Zagadnienia Naukoznawstwa" 2004 nr 1, s. 3-22; K. Abriszewski Teoria Aktora-Sieci Bruno Latoura, "Teksty Drugie" 2007 nr 1/2, s. 113-126. Por. także E. Bińczyk Inwazja ANT na "rynek" polski, "Teksty Drugie" $2010 \mathrm{nr}$ 1/2, S. 329-337.

4 Robert Kohler ocenia, że po gwałtownym rozwoju laboratory studies (począwszy od końca lat 70.) od lat 90. nastąpił zastój w systematycznych badaniach nad laboratoriami. Por. R.E. Kohler Lab history: reflections, "Isis" 2008 vol. 99, no. 4, s. 761-786.

5 W naszym projekcie myślimy o laboratorium humanistycznym jako modusie poznania, traktując je jako sposób tworzenia wiedzy humanistycznej. Mając na myśli modalność (sygnalizowaną przez wielostronne „jak") poznania, nie sprowadzamy go do idei, metafory, praktyki, infrastruktury, miejsca i przestrzeni czy instytucji, choć zarówno spacjalność, jak i wymiar organizacyjno-instytucjonalny w owej modalności mogą się zawierać. W ramach projektu przeanalizowaliśmy następujące przypadki: pracownia alchemiczna jako prefiguracja laboratorium humanistycznego (Dorota Wolska), „laboratorium wiedzowładzy” Jeremy'ego Benthama (Rafał Nahirny), Laboratorium Mundaneum Paula Otleta (Aleksandra Kil), laboratoryzacja terenu w antropologii społeczno-kulturowej (Adam Pisarek), Kulturoznawcza Biblioteka Aby'ego Warburga (Karolina Charewicz-Jakubowska), laboratoria szkoły lipskiej (Krzysztof Łukasiewicz), Teatr Laboratorium Jerzego Grotowskiego (Mirosław Kocur), laboratorium semiotyczne Jurija Łotmana (Jacek Małczyński), Laboratorium Antropologii Społecznej Claude’a Lévi-Straussa (A. Kil, J. Małczyński, D. Wolska), SenseLab (Magdalena Zamorska) oraz kolektywne posthumanistyczne praktyki badawcze (Joanna Sieracka). 
Latourowskie ujęcie laboratorium - choć stanowiło początkowo jedno ze źródeł inspiracji dla naszych badań i wydaje się już dobrze zadomowione w humanistyce - okazało się niewystarczające. Pojmując la b o r a t o r i u m jako modus poznania, sięgnęliśmy po metodę archeologiczną Foucaulta (zwłaszcza do jego projektu ,archeologii nauk humanistycznych" wyłożonego w Stowach i rzeczach). Można zauważyć, że perspektywa etnografii laboratorium (którą rekonstruujemy głównie na przykładzie Latoura) oraz Foucaultowska archeologia to dwie odrębne strategie badawcze - pierwsza polega na opisywaniu „nauki w działaniu”, zanim zdąży ona zasklepić się w czarnych skrzynkach, druga jest z konieczności retrospektywna, bo, jak wiemy od Foucaulta, episteme nie może pytać o samą siebie. W naszych badaniach nad fenomenem laboratorium humanistycznego - które z jednej strony jest dziełem in statu nascendi, a z drugiej ma już swoją historię i liczne prefiguracje - chcemy posplatać ze sobą etnografię i archeologię laboratorium. Celem tekstu nie jest jednak zadanie komparatystyczne (choć już wielu autorów i autorek próbowało konfrontować obu francuskich myślicieli, tropiąc różnice i podobieństwa w ich koncepcjach). Chcemy raczej pokazać, co czerpiemy z obu tych podejść. Zaczynamy od rozliczenia się z Latourem, któremu zawdzięczamy przede wszystkim wyczulenie na materialną/technologiczną stronę aktywności naukowej i u którego na próżno poszukiwaliśmy tożsamości laboratorium humanistycznego. Zainspirowani studiami Foucaulta, spoglądamy w humanistyczną przeszłość głębiej niż do lat 80 . XX wieku (jak datuje się początki medialabów, z którymi często łączy się współczesną fascynację laboratorium w humanistyce), uznając, że pozwoli to na odkrycie genealogii uwzględniającej więcej niżjedną linię w rodowodzie laboratorium humanistycznego (nie tylko technomedialną, infrastrukturalną). Perspektywa archeologiczna zarówno umożliwia wgląd we wciąż nierozpoznaną historię laboratoriów humanistycznych, jak i pozwala uruchomić „transcendentalny kołowrotek” i przyjąć pozycję „hipoepistemiczną”.

\section{Kto kogo naśladuje? Latour w laboratorium}

Podejmując problematykę laboratoryjną, nie sposób uniknąć koncepcyjnego zadłużenia się u Latoura, który - obok Karin Knorr-Cetiny, Trevora Pincha, Sharon Traweek, Michaela Lyncha i Harry’ego Collinsa - współtworzył etnografię laboratorium. Latour łączy drobiazgowe analizy empiryczne ze śmiałymi wywodami o charakterze metanaukowym. Jego prace objaśniają przede wszystkim sposoby działania laboratoriów i przyczyny ich spektakularnego 
sukcesu społecznego. Z biegiem lat w badaniach Latoura są eksplorowane różne aspekty laboratorium, a sama koncepcja laboratorium się zmienia.

Życiu laboratoryjnemu, książce napisanej przez Latoura wspólnie ze Steve'em Woolgarem i stanowiącej raport $\mathrm{z}$ badań przeprowadzonych $\mathrm{w}$ laboratorium neuroendokrynologicznym w The Salk Institute for Biological Studies, przypisuje się istotne znaczenie dla zainicjowania kolejnej przemiany badań nad nauką, szczególnie jej aspektu społecznego i materialnego. Henning Schmidgen uznał nawet, że wydane po raz pierwszy w 1979 roku Życie laboratoryjne odegrało rolę porównywalnie rewolucyjną z wydaną siedemnaście lat wcześniej Struktura rewolucji naukowych Thomasa Kuhna ${ }^{6}$. Badania w zakresie fizyki teoretycznej zawiodły Kuhna do przekonania o epistemicznej ważności wymiaru historycznego i społecznego nauki oraz podważenia modelu jej kumulacyjnego i liniowego rozwoju. Warto wspomnieć tu również o znaczeniu koncepcji Ludwika Flecka, u którego zadłużony był Kuhn, a wobec którego dług intelektualny post factum spłacił Latour7. Czym wyróżniało się Latourowskie podejście i dlaczego stanowiło przełom? Otóż Latour posługiwał się innym modelem nauki, na co zwrócił uwagę Jonas Salk w przedmowie do pierwszego wydania Życia laboratoryjnego:

[...] jednym z najbardziej interesujących rezultatów tej pracy jest dla mnie fakt, że Bruno Latour, filozof-socjolog, rozpoczął socjologiczne badanie biologii, a po drodze socjologię zaczął pojmować biologicznie. Jego sposób myślenia zmienił się pod wpływem naszych pojęć i tego, jak myślimy o organizmach, porządku, informacji, mutacjach itp. [...] widzimy tu socjologów dochodzących do wniosku, że ich praca należy do szerszego zakresu naszych naukowych aktywności, które z kolei należą do jeszcze szerszego organizowania się procesów życiowych (life in the process of organization) ${ }^{8}$

Podstawą modelu nauki nie jest tu zatem fizyka, lecz biologia z całą komplikacją i ekspansywnością jej kluczowej kategorii życia pojmowanego

6 H. Schmidgen Bruno Latour in pieces: intellectual biography, transl. G. Custance, Fordham University Press, New York 2015, s. 43.

7 B. Latour A textbook case revisited - knowledge as a mode of existence, w: The handbook of science and technology studies, ed. by E. Hackett et al., MIT, Cambridge, MA 2007, s. 83-112.

8 B. Latour, S. Woolgar Życie laboratoryjne. Konstruowanie faktów naukowych, przeł. K. Abriszewski i in., Narodowe Centrum Kultury, Warszawa 2020, s. 49. 
procesualnie. Ży ci e pojawia się tu także w innej odsłonie, mianowicie „codziennej" i „ludzkiej”, zoperacjonalizowanej antropologicznie m.in. przez ważnego dla Latoura autora - Michela de Certeau. Salk, przyglądając się temu, co w istocie Latour robił w jego instytucie, stwierdził, że po prostu opisywał on życie laboratoryjne, to znaczy życie codzienne naukowców. Dokonywał jego demistyfikacji, niekiedy, jak przyznał, bolesnej, ale jednocześnie koniecznej i społecznie pożytecznej, toteż Salk, jakkolwiek miał zastrzeżenia do obrazu swej pracy, wystąpił z postulatem, by każde laboratorium miało swojego „nadwornego" filozofa-socjologa?.

Przegląd najważniejszych publikacji Latoura od Życia laboratoryjnego po opublikowane w 2005 roku Splatając na nowo to, co społeczne prowadzi do wniosku, że jego pojmowanie laboratorium podlegało pewnym modyfikacjom, a w ostatnich latach temat ten pojawia się w Latourowskich pracach coraz rzadziej. Samo pytanie o ekwiwalencję metod pracy przyrodników i badaczy społecznych prawdopodobnie trapiło go już podczas badań terenowych w instytucie Salka. O ile z Życia laboratoryjnego można by wysnuć wniosek - wtedy uznawany za niezwykle kontrowersyjny, a i dziś zapewne nie dla wszystkich oczywisty - że ścisłowcy, pracując, są jak humaniści, o tyle w Splatając na nowo to, co społeczne pojawia się teza, że tekst w humanistyce jest "funkcjonalnym równoważnikiem laboratorium"10, a zatem to h u m a n i ś c i pracują jak ścisłow cy. Paralela ta - bez względu na to, jak skonfigurujemy człony porównania" ${ }^{11}$ jest możliwa, ponieważ Latour koncentruje uwagę na zapisach, urządzeniach inskrypcyjnych oraz tworzeniu tekstów naukowych jako clou pracy laboratoryjnej. Schmidgen, przestudiowawszy jego drogę intelektualną, tłumaczy, że skupienie na inskrypcjach (zapożyczone od Derridy) i na transmisji znaczeń stanowi kontynuację wcześniejszych

9 Taką rolę, jak się uważa, odgrywał Ernst Cassirer w Laboratorium/Bibliotece Aby'ego Warburga; zob. E. Skidelski Ernst Cassirer: the last philosopher of culture, Princeton University Press, Princeton-Oxford 2008, s. 90-91.

10 Teza ta była chętnie podchwytywana i rozwijana, w Polsce np. przez Ryszarda Nycza, zob. tegoż W stronę humanistyki innowacyjnej: tekst jako laboratorium. Tradycje, hipotezy, propozycje, "Teksty Drugie" 2013 nr 1/2, s. 239-255.

11 Zastanawiając się nad podobieństwem metod obserwatora (etnografa) i jego informatorów (naukowców), Latour i Woolgar stwierdzają: „Nie jest jednak jasne, kto kogo naśladuje. Czy to naukowcy imitowali obserwatora czy vice versa?". Dalej konstatują: „Podobieństwa te utrudniają obstawanie przy tym, że jest jakaś fundamentalna różnica między metodami «twardej» i «miękkiej» nauki". B. Latour, S. Woolgar Życie laboratoryjne, s. 336. 
zainteresowań egzegezą biblijną, pracami Rudolfa Bultmanna i analizą pism Charles'a Péguya.

WŻyciu laboratoryjnym Latour definiuje laboratorium jako „system zapisywania"12 czy „ośrodek intensywnej aktywności pisarskiej” (hive of writing acti$v i t y)^{13}$. Schmigden zaznacza, że głównym wątkiem tej książki są teksty laboratoryjne, niejako wbrew tytułowi, sugerującemu nade wszystko perspektywę etnograficzną, a także poniekąd życie w sensie biologicznym, stanowiące przedmiot zainteresowania badanego "plemienia” neuroendokrynologów. Obserwując codzienne aktywności naukowców i techników pracujących w laboratorium Rogera Guillemina oraz studiując przestrzenny podział laboratorium na część biurową (pisarską) i część warsztatową (bench), obserwator-etnograf (czyli figura tekstowa, którą Latour i Woolgar wprowadzili chyba dla skonfundowania czytelnika albo ukrycia faktu,że tylko Latour spędził dwa lata w terenie) uznaje, że choć nie ma fundamentalnej różnicy między jego procedurami poznawczymi a działaniami jego informatorów, to jednak różni ich wiele pod względem zasobów i inwestycji. Znajduje to odzwierciedlenie $\mathrm{w}$ wiarygodności i solidności konstruowanych twierdzeń (chociaż nie ma różnic w samych źródłach tej wiarygodności - opis etnografa nie jest ani lepszy, ani gorszy od opisów tworzonych przez samych naukowców) ${ }^{14}$. Wreszcie badacz przyznaje: „Jedyna różnica jest taka, że oni mają laboratorium. My z kolei mamy tekst, ten tekst"15. Można się spierać, czy przywołana już późniejsza teza o tekstowym odpowiedniku laboratorium (tekst to „miejsce prób, eksperymentów, symulacji”'16) zostaje wyrażona dobitniej, czy stanowi echo tych samych przekonań.

Podobny problem pojawia się w Nadziei Pandory (1999) w rozdziale o laboratorium w terenie (tym razem rozproszonym i mobilnym, w przeciwieństwie do przypadku z Życia laboratoryjnego), którego bohaterami są pedolodzy i botanicy badający amazoński las. Latour znów jest tu obserwatorem, wyrusza z przyrodnikami na wyprawę badawczą i pyta: „pod jakim względem mój sposób mówienia o tym fotomontażu różni się od sposobu, w jaki moi

Tamże, s. 98.

Tamże, s. 96.

Zob. tamże, s. 338.

Tamże, s. 339.

B. Latour Splatając na nowo to, co społeczne. Wprowadzenie do teorii aktora-sieci, przeł. A. Derra, K. Abriszewski, Universitas, Kraków 2010, s. 216. 
informatorzy opowiadają o glebie?"17. Latour wprowadza pojęcie krążącej referencji (i krokowej koncepcji wiedzy przeciwstawionej jej tradycyjnej wersji skokowej), która stanowi model poznania właściwego nie tylko nauce. Jest jednak wyraźnie świadomy różnic między własnym tekstem a raportami badanych przez siebie gleboznawców; pisze o „innym rodzaju odniesien”" w owym łańcuchu referencji i braku możliwości tak sprawnego prześledzenia kroków pośrednich ${ }^{18}$. Czyżby więc laboratorium humanistyczne (tekstowe) nie dysponowało podobną siłą jak to przyrodoznawcze? I czy potrzebne nam w ogóle takie konfrontacje? Czy nie lepiej porzucić tutaj „zbawienną poręcz” Latourowskiej teorii?

Myślenie o laboratorium w kategoriach siły najwyraźniej się uwidacznia w tekście poświęconym Ludwikowi Pasteurowi (1983). Latour podtrzymuje w nim tezę, że laboratoria są obsesyjnie skupione na zapisach, działają w agonistycznym polu i dzięki modalizacjom zamieniają argumenty w fakty naukowe (to wątki znane już z Życia laboratoryjnego). Pojawia się jednak nowy element, który zresztą utrwali się w późniejszej recepcji i zdominuje myślenie o laboratorium w studiach nad nauką i technologią. Na podstawie analizy procesu prowadzącego do wynalezienia przez Pasteura szczepionki przeciw waglikowi Latour pokazuje przede wszystkim, że laboratorium to „technologiczna konstrukcja służąca gromadzeniu siły dzięki możliwości popełnienia licznych pomyłek"19. Konstrukcja ta ma swoistą topologię, znoszącą różnice

17 B. Latour Nadzieja Pandory. Eseje o rzeczywistości w studiach nad naukg, przeł. K. Abriszewski i in., Wydawnictwo Naukowe UMK, Toruń 2012, s. 61.

Tamże, s. 110-111. Próbę przełożenia modelu krążącej referencji w obszary nauk innych niż przyrodoznawstwo podjął Krzysztof Abriszewski, opisując warsztat pracy oraz problem odniesień $\mathrm{w}$ dyskursie naukowym $\mathrm{w}$ badaniach socjologicznych wykorzystujących ankiety i w filozofii (zob. tegoż Poznanie, zbiorowość, polityka. Analiza teorii aktora-sieci Bruno Latoura, Universitas, Kraków 2008, s. 33-51). Doszedł on do wniosku, że „zalew papierów”, jakiego doświadcza filozof, jest nawet większy niż produkcja inskrypcji w innych dziedzinach. O możliwości studiów empirycznych nad technologiami pracy umysłowej humanistów wspomina także Łukasz Afeltowicz (Modele, artefakty, kolektywy. Praktyka badawcza w perspektywie współczesnych studiów nad naukg, Wydawnictwo Naukowe UMK, Toruń 2012). Choć Afeltowicz na podstawie analizy praktyk związanych z czytaniem i pisaniem tekstów naukowych wskazuje, że praca humanistów ma charakter rozproszony i usytuowany (nie dzieje się tylko "w głowie"), to odrzuca zarazem ideę, iż humaniści dysponują odpowiednikiem laboratorium (kluczowy jest dla niego aspekt interakcji i kolektywności - na pierwszy rzut oka takie funkcje pełniłoby w humanistyce seminarium, ale Afeltowicz uznaje je raczej za agon niż za pole zbiorowej pracy).

19 B. Latour Dajcie mi laboratorium, a poruszę świat, przeł. K. Abriszewski, Ł. Afeltowicz, "Teksty Drugie" $2009 \mathrm{nr} 1 / 2$, s. 188. 
między mikro- i makroskalą, między tym, co wewnątrz, i i tym, co na zewnątrz laboratorium. Aby działać skutecznie (tworzyć wiarygodne teorie i narzędzia, zdobywać zainteresowanie opinii publicznej i grantodawców), laboratorium musi rozciągać się poza swoje mury - przekształcać swoje otoczenie, budować tory, po których podróżują naukowe fakty ${ }^{20}$.

\section{Latour: protokół rozbieżności}

Dla naszych badań nad laboratorium humanistycznym wizja Latoura od początku stanowiła jedno z ważniejszych źródeł inspiracji. Czytając jego stwierdzenia dotyczące laboratoriów przyrodoznawczych, rozważaliśmy, czy można je sensownie przełożyć (po Latourowsku - dokonać translacji) na obszar humanistyki. Ujmując rzecz szerzej, pytaliśmy, czy metody i narzędzia wypracowane w ramach rozbudowanych i już zasłużonych studiów nad nauką i technologią - które przyczyniły się niewątpliwie do popularyzacji tematu laboratoriów w humanistyce - mogłyby posłużyć do zadania o charakterze autoetnograficznym; do próby wyjaśnienia fenomenu laboratoriów humanistycznych ${ }^{21}$. Byliśmy świadomi, że sięgając po modele i wyjaśnienia dotyczące pracy naukowców z dziedziny nauk przyrodniczych, musimy działać ostrożnie, ich ekstrapolacja czy prosta aplikacja mogłaby bowiem zniweczyć projekt badań laboratorium humanistycznego, u którego podstaw legło założenie, iż nie kopiuje ono swego przyrodoznawczego odpowiednika ${ }^{22}$. Jakkolwiek transpozycja tego ujęcia na grunt humanistyki jest

Ta metafora powróci jeszcze u Latoura, zob. tegoż Science in action: how to follow scientists and engineers through society, Harvard University Press, Cambridge, MA 1987, s. 250.

Inni autorzy zajmujący się laboratoriami w humanistyce sięgają także po narzędzia socjologii nauki, zob. J. W. Malazita, E.J. Teboul, H. Rafeh Digital humanities as epistemic cultures: how DH labs make knowledge, objects, and subjects, "Digital Humanities Quarterly" 2020 vol. 14, no. 3, http://www.digitalhumanities.org/dhq/vol/14/3/000465/000465.html (29.01.2021); M. Maryl et al. A Case study protocol for meta-research into digital practices in the humanities, "Digital Humanities Quarterly" 2020 vol. 14, no. 3, http://www.digitalhumanities.org/dhq/ $\mathrm{vol} / 14 / 3 / 000477 / 000477 . h t m l$ (29.01.2021). Ponadto Urszula Pawlicka-Deger rozpoczęła projekt badawczy stanowiący etnografię laboratorium humanistyki cyfrowej w londyńskim King's Digital Lab, zob. https://kdl.kcl.ac.uk/blog/behind-text/ (29.01.2021).

Podobne pytania dotyczące imitacji laboratoriów przyrodniczych w naukach humanistycznych stawialiśmy, analizując przypadek Laboratorium Antropologii Społecznej Claude'a Lévi-Straussa. Zob. A. Kil, J. Małczyński, D. Wolska Z archeologii laboratorium humanistycznego. Zwodniczy przypadek Laboratoire d'anthropologie sociale Claude'a Lévi-Straussa, "Konteksty. Polska Sztuka Ludowa" 2020 nr 3, s. 48-53. 
problematyczna z kilku względów, pozostaje ono dla nas ważnym punktem odniesienia, ponieważ pozwala docenić wymiar materialności myślenia i pracy badawczej (znaczenie infrastruktury i czynników pozaludzkich), wciąż dla wielu humanistów nieprzejrzysty. Latourowski nacisk na inskrypcje i urządzenia zapisujące, na teksty i warsztat pisarski naukowców, oparcie modelu praktyki naukowej na działalności egzegetycznej tym bardziej przyczyniają się do tego, że tę wizję laboratorium można odnieść do humanistyki. Ponadto, choć nie uprawiamy intensywnej etnografii laboratorium tak jak Latour, badamy konkretne przypadki i jesteśmy zainteresowani materialnymi układami i praktykami laboratoryjnymi. Wprawdzie badamy laboratorium humanistyczne jako modus poznania, ale przyglądamy mu się także od strony narzędzi, przestrzeni, form realizacji, nie traktując go jako określonego typu racjonalności. Nie mówimy zatem głosem podobnym do głosu teoriocentrycznych epistemologów nauki, od których odżegnuje się Latour ${ }^{23}$. Inspirujące jest również Latourowskie myślenie o laboratorium przyrodniczym jako przestrzeni prób i błędów ${ }^{24}$. Czy laboratorium humanistyczne stanowi podobną przestrzeń metodycznego błądzenia? Czym różnią się błędy popełniane przez humanistów i przyrodoznawców? Czy mają one wyłącznie epistemiczny czy także etyczny charakter? Na te pytania nie znajdujemy u Latoura odpowiedzi.

Istotną rolę w Latourowskim myśleniu o laboratorium odgrywa dźwignia służąca do zmiany skali i układu sił. Możność przełożenia dźwigni z pozycji słabej na silną oznacza dokonanie zmian w porządku naturalnym i społecznym. Czy humanistyka dysponuje taką możliwością? Pytanie to nabiera znaczenia w kontekście formułowanych współcześnie pod adresem humanistyki roszczeń co do jej „wpływu społecznego”. Wywnętrzenie laboratorium (które nie dzieje się automatycznie, lecz jest wynikiem ciężkiej pracy naukowej: produkowania i nakładania kolejnych inskrypcji oddających momenty wielokrotnych przemieszczeń), prowadzi do l a b o r a t o r y z a c j i świata ${ }^{25}$.Zmiana rzeczywistości (porządku społecznego i naturalnego, które, jak wiemy, są dla Latoura jedynie umownie rozdzielone), przesuwanie archimedesowskiej dźwigni jest zatem pożądanym celem pracy laboratoriów. O ile akademickie wieże z kości słoniowej i zamknięci w nich często humaniści

23 Zob. K. Abriszewski, R. Wiśniewski Wstęp, w: B. Latour, S. Woolgar Życie laboratoryjne, s. 16.

24 B. Latour Dajcie mi laboratorium, a poruszę świat, s. 187-188.

25 Pisząc o "wywnętrzeniu się laboratorium", chcemy podkreślić, że opozycja wnętrze-zewnętrze u Latoura ma charakter aporii, a Latour dokonuje w derridiańskim stylu jej dekonstrukcji. 
mogą przypominać przestrzenie metodycznych prób i błądzenia - chociaż i tu trzeba by wziąć pod uwagę badania wprost „zaangażowane" - o tyle trudniej wyobrazić sobie inne elementy Latourowskiej koncepcji wcielone w laboratorium humanistyczne.

Po pierwsze, można zapytać sceptycznie, czy humanistyka ma w swoim arsenale podobną dźwignię. Jeśli nie, to czy odnoszenie się do koncepcji Latoura nie skutkuje autodeprecjacją, utrwaleniem się obrazu wybrakowanej humanistyki - nadal niedorastającej do wizji laboratorium przyrodoznawczego, które sprawnie manipuluje skalą i solidniej umacnia swoje efekty poznawcze.

Po drugie, trzeba się zastanowić, czy humaniści są skłonni przejść na pozycję „silną" - czy mają ambicję, by laboratoryzować świat, i czy są gotowi wziąć za to odpowiedzialność (świadomi ryzyka płynącego z utraty uprzywilejowania epistemicznego). Czy raczej zakładając własne laboratoria, humanistki nie chcą laborat oryzować przede wszystkim samej humanistyki, np. broniąc jej miejsca we współczesnym skorporatyzowanym uniwersytecie, przekształcając jej nawyki poznawcze i modele pracy?

Po trzecie, w świetle teorii Latoura każdy rodzaj pracy naukowej można uznać za laboratoryjny, nie ma więc u niego podziału na nauki laboratoryjne i nielaboratoryjne. Ponadto nie zauważa on zróżnicowania laboratoriów, nie dostrzega ich historycznej złożoności ${ }^{26} \mathrm{i}$ skupia się przede wszystkim na laboratoriach przyrodniczych. Jego teoria nie pozwala zatem uwzględnić tożsamości laboratorium humanistycznego jako modusu poznania ani odróżnić go od innych nielaboratoryjnych postaci badań humanistycznych.

Po czwarte, problematyczne jest również samo znaczenie terminu „humanistyka" u Latoura. W liście skierowanym do redaktorów czasopisma "New Literary History", w którym autorzy podjęli próbę namysłu nad kondycją humanistyki przez pryzmat jego ostatnich prac, tłumaczył, że słowo to w języku francuskim kojarzy się raczej z literaturą - czy też szerzej pisaniem - niż z określonym polem badawczym. Zapytany o rolę humanistyki (spowinowacając ją z filozofią), określa ją jako infrajęzyk i jednocześnie porównuje do dyplomacji. „W tym sensie - pisze - określiłbym «humanistów» jako tych, którzy umożliwiają relacje dyplomatyczne. Odgrywają rolę nieco ważniejszą niż rola mâitre d'hôtel, lecz znacznie mniej istotną niż strony

26 Zróżnicowanie praktyk naukowych, także w odniesieniu do laboratoriów przyrodniczych, interesowało z kolei Karin Knorr-Cetinę, zob. tejże Epistemic cultures: how the sciences make knowledge, Harvard University Press, Cambridge-London 1999. 
negocjacji. To zajęcie podobne do tego, które nazwalibyśmy rolą «szefa protokołu», wprawdzie szefa, ale tylko protokołu"27. Według Latoura stronami tych negocjacji są artyści i naukowcy, nie dookreśla on jednak, co stanowi ich przedmiot i na czym dokładnie polega ta mediująca (dyplomatyczna) rola humanistyki.

\section{Archeologia wiedzy: transcendentalna mobilność}

Drugim ważnym punktem odniesienia naszego projektu jest archeologia wiedzy Michela Foucaulta. Odcinając się od fenomenologii, kontynuował on tradycję francuskiej epistemologii rozwijaną przez Gastona Bachelarda i Georges'a Canguilhema, której główną zasługą było uhistorycznienie poznania. Ogólna formuła archeologii wiedzy została wyłożona już w Słowach irzeczach (1966) ${ }^{28}$ :

archeologia, zajmująca się ogólną przestrzenią wiedzy, jej konfiguracjami i modusem bytu ukazujących się tam rzeczy, określa systemy synchroniczności oraz serię niezbędnych i wystarczających mutacji, które wyznaczają próg nowej pozytywności. ${ }^{29}$

W swej „archeologii nauk humanistycznych”, która miała stanowić propozycję alternatywną wobec historii nauki i idei, Foucault próbował określić „historyczne a priori” konstytuujące wiedzę $e^{30}$. To episteme (pole epistemologiczne) wyznacza granice poznania, reguły racjonalności i zasady prawdomówności, określa sposoby postrzegania, klasyfikowania i reprezentowania rzeczywistości.

W Stowach irzeczach Foucault przygląda się przemianom wiedzy prowadzącym do wyłonienia się na początku XIX wieku dziedziny nauk humanistycznych (sciences humaines). Choć brzmi to jak nader ambitne, bezkresne przedsięwzięcie, przekraczające ramy jednej książki i siłą rzeczy sprowadzające się

27 B. Latour Life among conceptual characters, "New Literary History” 2016 vol. 47, no. 2/3, s. 474.

28 Jak pisał Deleuze, krótko po ukazaniu się Słów i rzeczy książka została porównana do Mein Kampf, a w latach 8o. stała się przedmiotem krytyki tzw. obrońców praw człowieka. Zob. G. Deleuze Foucault, przeł. M. Gusin, Wydawnictwo Naukowe DSWE TWP, Wrocław 2004, s. 35. M. Foucault Słowa i rzeczy. Archeologia nauk humanistycznych, przeł. T. Komendant, słowo/obraz terytoria, Gdańsk 2006, s. 11. 
do nieco podręcznikowego trawersu w poprzek dziejów humanistyki, jego analizy są skoncentrowane na konkretnym motywie przewodnim. Mianowicie studiuje on historię ładu rzeczy („stosunek reprezentacji do tego, co w niej dane"). Więcej miejsca niż samym naukom humanistycznym poświęca rekonfiguracjom w polach epistemologicznych, które poprzedziły wyłonienie się współczesnej mu postaci poznania. Jego archeologia (jako „opis systemu pozytywności") prezentuje zatem nieciągłości między myślą renesansową i - przede wszystkim - między klasycyzmem (stulecia XVII i XVIII) a nowoczesnością (od wieku XIX aż do czasów współczesnych).

Nową konfigurację wiedzy, dokonującą się w XIX wieku, Foucault wyobrażał sobie w formie nietypowej figury geometrycznej, jaką jest trójścian ${ }^{31}$. Jego ściany tworzą: (1) nauki ścisłe (matematyka, fizyka), które mają charakter dedukcyjny i cechują się wysokim stopniem formalizacji, (2) nauki empiryczne (językoznawstwo, biologia, ekonomia) oraz (3) filozofia. Nauki humanistyczne (Foucault zalicza do nich psychologię, socjologię, etnologię, historię, badania literatury i mitów czy psychoanalizę) dryfują w przestrzeni rozpościerającej się między tymi trzema ścianami, stanowiąc niebezpieczeństwo dla swych sąsiadów. Wiąże się ono z „antropologizacją” (czy też socjologizacją, psychologizacją bądź historycyzacją) wiedzy - w czym wyspecjalizowały się studia socjologiczne nad nauką - której inne nauki starają się uniknąć. Humanistyka podkopuje zatem fundamenty, na których opiera się trójścian wiedzy. Tym, co ją wyróżnia, jest "transcendentalna mobilność" (Tomasz Swoboda, polski tłumacz tego rozdziału Słów i rzeczy, przekłada mobilité jako kołowrotek), która sprawia, że nieustannie „same siebie demistyfikują: od bezpośredniej i niekontrolowanej oczywistości kroczą ku formom mniej przejrzystym, lecz bardziej fundamentalnym"32. Ta „transcendentalna nadbudówka", przejawiająca się w ciągłej reflektywności, stanowi ich differentia specifica. Archeologia ${ }^{33}$ wiedzy ma służyć przede wszystkim do badania historii nauk humanistycznych ze względu na charakterystyczną dla

31 Wizualizacji trójścianu i jego odniesienia do problematyki laboratorium podjęła się grupa badawcza (w składzie: Aleksandra Brylska, Franciszek Chwałczyk, Maciej Kwietnicki, Maksymilian Sawicki, Aleksandra Skowrońska) w ramach projektu Mediated Environments kierowanego przez Agnieszkę Jelewską i Michała Krawczaka (HAT UAM), https://mediatedenvironments. org/project/publikacje/ (23.01.2021). chela Foucaulta archeologie nauk humanistycznych, Wydawnictwo UMCS, Lublin 2013, s. 104-114. 
nich „niedojrzałość”34 przejawiającą się w ustawicznym opóźnieniu i ciągłym niedorozwinięciu. To zatem, co może świadczyć o słabości nauk przyrodniczych, jawi się jako racja bytu humanistyki. Historycy nauki, jak zauważa Foucault we wprowadzeniu do angielskiego wydania Stów i rzeczy, zajmują się głównie „naukami szlachetnymi” (matematyką, kosmologią czy fizyką). Tymczasem dyscypliny empiryczne, badające żywe istoty, również mają własne „kody wiedzy" ${ }^{35}$.

Archeologia wiedzy patrzy nie do tyłu, lecz raczej w głąb, chcąc „uchwycić modyfikacje na archaicznym poziomie; to, co umożliwia poznanie i modus bytu tego, co poznawane" ${ }^{36}$. Stawia ona przed badaczem/badaczką rozmaite wyzwania, o których instruktywnie pisał Foucault. Archeolog wiedzy musi odróżniać ruchy i zmiany powierzchniowe od tych bardziej fundamentalnych (wśród tych pierwszych mogą być „nowe formy dyskursu naukowego”, "redystrybucja opinii i mniemań" ${ }^{37}$ ), oddzielać ciągłości od quasi-ciągłości, unikać także postawy prezentystycznej (przejawiającej się np. pisaniem o ekonomii zamiast o analizie bogactw w czasach klasycyzmu) i nie skupiać się na odtwarzaniu problemów czy debat uważanych za kluczowe dla stylu myślowego danej epoki. Foucault zaznacza, że w dziejach poznania mamy do czynienia z powrotami - np. w myśli nowoczesnej wraca "gęstość języka", znana już w renesansie, nowoczesność zachowuje też znaną z klasycyzmu tablicę jako formę wiedzy ( $\mathrm{u}$ Foucaulta to synekdocha myślenia taksonomicznego, tabularnego) - ale to, co wraca, nigdy nie jest dokładnie tym samym. Dlatego archeologia wiedzy eksponuje raczej nieciągłości, chcąc zerwać z iluzją kontynuacji, którą w historii nauki i idei podtrzymują takie pojęcia, jak tradycja, duch epoki, umysłowość, rozwój, teleologia, oddziaływanie. Wbrew historykom uprzywilejowującym pojęcie ciągłości, których uwaga koncentruje się na badaniu „niewzruszonych procesów” $i$,stałych porządków”, Foucault interesuje się momentami zerwania i historycznymi „pęknięciami”. Do jednego z takich tąpnięć doszło na początku XIX wieku, kiedy dokonała

34 Termin "nauki niedojrzałe" (immature sciences) w odniesieniu do Słów i rzeczy wprowadził lan Hacking: Michel Foucault's Immature Science, w: tegoż Historical Ontology, Harvard University Press, Cambridge 2002.

M. Foucault Przedmowa do angielskiego wydania "Słów i rzeczy”, w: tegoż Filozofia, historia, polityka. Wybór pism, przeł. D. Leszczyński, L. Rasiński, Wydawnictwo Naukowe PWN, Warszawa 2000. 
się „redystrybucja episteme”, a idea mathesis ustąpiła pola narodzinom nauk humanistycznych ${ }^{38}$.

Foucault interesował się „nieświadomością nauki”, ale w pozytywnym tego słowa znaczeniu, nie chodziło mu o identyfikację „niewidzialnych przeszkód”, jakie napotyka nauka, lecz o to by „wydobyć na jaw pozytywną nieświadomość wiedzy: poziom, który wymyka się świadomości badacza, ale który mimo to jest częścią naukowego dyskursu, tym, co podważa jego prawomocność i usiłuje naruszyć jego naukową naturę"39. Dlatego - jak pisze Ian Hacking w swoim komentarzu o Stowach irzeczach - Foucault stara się zatrzeć wagę instancji autorskiej, zasadniczo unikając pisania historii z perspektywy wielkich nazwisk ${ }^{40}$.

\section{Perspektywa hipoepistemologiczna}

Obierając za przedmiot uwagi fenomen tak popularny współcześnie, jak laboratorium humanistyczne, sięgamy po archeologię wiedzy Foucaulta, aby spleść ją z socjologizującym spojrzeniem charakterystycznym dla studiów nad nauką i technologią oraz socjologii wiedzy. Korzystamy z myśli Foucaultowskiej, choć w pełni się z nią nie utożsamiamy. Co więcej, jesteśmy świadomi, że połączenie tych dwóch perspektyw może się wydawać ryzykowne ${ }^{41}$.

Myśląc o laboratorium humanistycznym, wykorzystujemy projekt Foucaulta z kilku względów. Mówiąc jego słowami, przyjmujemy specyficzną ana- czy raczej „hipoepistemologiczną"42 pozycję refleksji humanistycznej, podkreślamy jej samozwrotność i reflektywność, i uprawiamy właściwie

38 Tamże, s. 309-314.

M. Foucault, Przedmowa do angielskiego wydania „Słów i rzeczy”, s. 45.

I. Hacking Michel Foucault's Immature Science, s. 90.

W literaturze jednak nie brakuje prób zestawiania myśli Foucaulta i Latoura, zob. O. Pyyhtinen, S. Tamminen We have never been only human: Foucault and Latour on the question of the anthropos, "Anthropological Theory” 2011 no. 11 (2), s. 135-152; L. Hengehold Revolution from between: Latour's reordering of things in "We Have Never Been Modern", "Qui Parle" 2015 vol. 24, no. 1, s. 89-124; specjalne wydanie tematyczne czasopisma "Le Foucauldien": S. Ganahl, P. Kilian (ed.), Foucault meets Latour, "Le Foucauldien" 2019 no 5/1, https://foucaldien.net/collections/special/ foucault-meets-latour/ (24.01.2021). 
"humanistykę humanistyki" ${ }^{43}$. Podobnie jak on pozostajemy także w kręgu episteme kultury Zachodu ${ }^{44}$. Nie piszemy jednak dalszego ciagu Stów i rzeczy, aczkolwiek do ich kontynuacji skłaniałoby chociażby to, że przedstawione tam drobiazgowe analizy nie wykraczają dalej niż po pierwsze dekady XX wieku ${ }^{45}$. Foucault, odnosząc się do prac Goldsteina, Maussa, Dumezila i Freuda, wyróżnia wtedy „historyczny gradient” w trwaniu nauk humanistycznych. Patrząc z perspektywy kolejnych kilkudziesięciu lat, można byłoby się pokusić o wyróżnienie kolejnych takich gradientów, jeśli nie nowych form episteme, nowych podstaw pola epistemologicznego.

Foucault pisze, że renesansowe widowiska czy nowoczesne ogrody botaniczne, gabinety historii naturalnej i tablica taksonomiczna stanowiły "na płaszczyźnie instytucjonalnej” odpowiedniki „wykroju wiedzy”46 (właściwej im episteme). Laboratorium (rozumiane tu podobnie jako pewien model instytucjonalny) moglibyśmy analogicznie uznać za korelat pewnego sposobu poznania. Czy ten ostatni należy uważać za przejaw nowej, współczesnej nam rekonfiguracji pola wiedzy, czy tylko foucaultowski „fałd” w polu wiedzy, powierzchniową zmianę? Według Foucaulta „[n]a początku XIX wieku pole epistemologiczne rozpada się na kawałki”, a „[p]ojawienie się człowieka i powstanie nauk humanistycznych wiąże się ze swego rodzaju dematematyzacją"47.

Jak celnie podsumowuje Hacking, Stowa i rzeczy traktują o nieświadomości i nieartykułowalności pola epistemicznego - innymi słowy, episteme nie jest w stanie zapytać o samą siebie. Mamy zatem wątpliwość, czy my - pracując w laboratorium humanistycznym w XXI wieku, w „zlaboratoryzowanym” polu wiedzy - możemy pytać o poznawczy status laboratorium. Współczesna humanistyka zapytuje chętnie o swoje laboratoria (czego również nasz projekt jest dowodem) - Foucault przestrzegał z kolei przed skupieniem się na debatach toczonych przez uczestników, na wsłuchiwaniu się w „opinie

43

M. Foucault Słowa i rzeczy, s. 318.

Takie podejście zresztą przeważa w studiach historycznych i socjologicznych nad praktykami naukowymi. Wyjątkiem mogą być próby podjęte przez Rensa Boda, zob. tegoż Historia humanistyki.Zapomniane nauki, przeł. R. Pucek, Aletheia, Warszawa 2013.

Zob. M. Foucault Słowa i rzeczy, s. 323-324.

Tamże, s. 130.

Tamże, s. 311, 314. Ten proces redystrybucji pola epistemicznego wyłania się z analizowanych w ramach naszego projektu laboratoriów szkoły lipskiej, Aby'ego Warburga czy Mundaneum Paula Otleta. 
i mniemania". Zarazem sam przeczuwał, że opisana przez niego nowoczesna episteme, w której polu narodziły się nauki humanistyczne wraz z ich przedmiotem - człowiekiem, chyli się ku upadkowi pod wpływem ekspansji ję$z \mathrm{ka}^{48}$. Z dzisiejszej perspektywy w kontekście posthumanistyki intuicje Foucaulta o „śmierci człowieka" nabierają innego znaczenia. Pojawia się pytanie, czy nie jesteśmy świadkami nowych rekonfiguracji w polu wiedzy, a miejsca Foucaultowskiego „trójścianu” nie zajmuje nowa figura.

Kluczowe dla nas pojęcie modusu poznania nie jest tożsame z Foucaultowską episteme. Ważne jest dla nas jego rozróżnienie na wiedzę rozumianą jako science (connaissance) i knowledge (savoir). Pierwsza z nich ma charakter zinstytucjonalizowany i dyscyplinarny, druga zawiera się w praktykach dyskursywnych czy artefaktach i stanowi warunek wyłonienia się tej pierwszej. Hacking tłumaczy savoir jako „wiedzę głęboką" (depth knowledge) a connaissance jako „wiedzę powierzchniową" (surface knowledge) 49 . Kierując się metodą archeologiczną, nie szukamy więc jednoznacznego źródła laboratorium humanistycznego i nie dążymy do skonstruowania jego liniowej, jednolitej i ciągłej historii. Chcemy uwzględnić rekurencyjność i udział przypadku w procesie konstytuowania się tegoż laboratorium. Między analizowanymi w naszym projekcie przypadkami Benthama, szkoły lipskiej, antropologicznym laboratorium Haddona, laboratorium nauki o obrazie Aby'ego Warburga, Paula Otleta, Teatrem Laboratorium czy kanadyjskim SenseLabem nie ma prostych zależności, nawiązań i kontynuacji. Dlatego, podążając tropem Foucaulta, nie chcemy mówić o idei laboratorium humanistycznego, co zakładałoby, że między tymi różnymi przedsięwzięciami istnieje ciągłość. Zachowując myśl Foucaulta o nieciągłości wiedzy i powracaniu nigdy-nie-tego-samego, posługujemy się pojęciem prepostfiguracji (preposteryjnych prefiguracji) - za jego pomocą sondujemy pole wiedzy, pozwalając sobie na „wcięcia”, na spojrzenie wycinkowe, mając świadomość tego, że nasz opis nie jest tak systematyczny jak praca Foucaulta.

\section{Latour czyta Foucaulta}

We wspomnianym już liście Latour, próbując odpowiedzieć na pytanie, jak rozumie humanistykę, daje wyraz swojej fascynacji myślą Nietzschego, Derridy

\footnotetext{
48 Tamże, s. 346.

49 I. Hacking Michel Foucault's Immature Science, s. 90.
} 
czy Péguya, których określa mianem „figur myślowych"50. Z kolei w innym wywiadzie to Gilles'a Deleuze'a i Michela Serres'a uznaje za „największych francuskich filozofów”' . Jak mówi: „Czytałem Deleuze’a bardzo dokładnie i byłem pod większym wpływem jego prac niż Foucaulta czy Lyotarda"52. Jakkolwiek wpływ koncepcji „wiedzowładzy” Foucaulta na studia z zakresu studiów społecznych nad nauką jest rozpoznany ${ }^{53}$, to związki między Latourowską etnografią laboratorium a Foucaultowską archeologią wiedzy nie są już tak oczywiste.

Sam Latour do Foucaulta odwołuje się sporadycznie. W Nadziei Pandory posługuje się zapożyczonym od autora Stów i rzeczy pojęciem urządzenia (dispositifs). Jak tłumaczył sam Foucault: „usiłuję uchwycić za pomocą tego słowa zasadniczo heterogeniczną całość, na którą składają się dyskursy, instytucje, budowle architektoniczne, ustawy, prawa, środki administracyjne, wypowiedzi naukowe, stanowiska filozoficzne, etyczne, filantropijne, krótko mówić to, co wypowiedziane, jak i niewypowiedziane. Natomiast samo urządzenie to sieć pomiędzy tymi elementami"54. Zapytany o to, czy urządzenie zastępuje pojęcie episteme, wyjaśniał, że stanowi ono pewien "przypadek" episteme, że zawsze jest ono określone zarówno granicami wiedzy, jak i władzy. Episteme ma charakter dyskursywny, tymczasem urządzenie łączy różne elementy, nie tylko dyskursywne. W Splatajac na nowo to, co spoteczne Latour wpisuje Narodziny kliniki $\mathrm{w}$ „długi trend w materializowaniu niematerialnych technologii”55.

50 B. Latour Life among conceptual characters, s. 465.

51 Poglądy Serres’a były też istotną inspiracją dla Foucaulta. Serres'a, Foucaulta i Latoura łączą sprzeciw wobec tradycyjnego pojmowania i uprawiania historii oraz relacjonizm. Pojęcie pragmatogonii, którym Latour posługuje się w Nadziei Pandory, pochodzi od Serres'a, podobnie jak rozumienie quasi-przedmiotów i translacji (zob. E. Bińczyk Obraz, którynaszniewala. Współczesne ujęcia języka wobec esencjalizmu i problemu referencji, Universitas, Kraków 2007, s. 205, 218). O związkach myśli Foucaulta i Serres'a zob. D. Webb, Microphysics. From Bachelard and Serres to Foucault, "ANGELAKI. Journal of the theoretical humanities” 2005 vol. 10, no. 2, s. 123-133.

T.H. Crawford An interview with Bruno Latour, "Configurations" 1993 vol. 1, no. 2, s. 262, cyt. za: H. Schmidgen Bruno Latour in pieces: intellectual biography, s. 6.

53 Zob. M. Wróblewski Teoria aktora-sieci, zaangażowany program studiów nad nauką a problem polityczności, „Prace Kulturoznawcze” 2015 t. 18, s. 145-164.

Gry i zabawy Michela Foucaulta. Michel Foucault w rozmowie z redakcją "Ornicar?", "Kronos" $2010 \mathrm{nr}$ 3, S. 199.

M. Foucault Narodziny kliniki, przeł. P. Pieniążek, Wydawnictwo KR, Warszawa 1999, s. 108. Uwaga ta pojawia się w przypisie do fragmentu, w którym Latour pisze o roli przedmiotów w naukach społecznych: „Ponieważ jednak przedmioty odgrywają poślednie i ograniczone role 
WŻyciu laboratoryjnym z kolei, kiedy pisze o zdobywaniu wiarygodności przez naukowców, wspomina o „politycznej ekonomii prawdy”. Stwierdza także, że dokonane przez Foucaulta "uwydarzeniowienie" nauki „trafia w sedno konstrukcji faktów"56. Jeśli według Foucaulta procedura ta polega na śledzeniu powiązań między wiedzą a mechanizmami przymusu, czynnikami legislacyjnymi czy układami materialnymi ${ }^{57}$, to nie różni się ona tak bardzo od teorii aktora-sieci. Podobnie pojęcie puryfikacji, które oprócz translacji odgrywa kluczową rolę w Nigdy nie byliśmy nowocześni, pojawia się w Słowach i rzeczach. Choć nie sposób dowieść, że Latour dokonuje tu „translacji” tej kategorii, jego rozumienie puryfikacji bliskie jest Foucaultowskiemu:

Epoka klasyczna nadaje historii odmienny sens: chodzi o to, aby po raz pierwszy objać dociekliwym spojrzeniem same rzeczy, a następnie zapisać to, co zostało ujrzane w bezbarwnych, neutralnych i wiernych słowach. Jasne jest, że przy tej „puryfikacji” pierwszą formą historii, jaka powstała, musiała być historia natury. ${ }^{58}$

\section{Podsumowanie}

Zadając sobie pytanie, jak badać laboratorium humanistyczne, poszukiwaliśmy inspiracji najpierw w studiach socjologicznych i antropologicznych nad nauką, by wreszcie powrócić do klasycznej - acz może rzadko już odświeżanej w lekturze - archeologii nauk humanistycznych. Foucaulta przeczytaliśmy zatem preposteryjnie ${ }^{59}$, tak jakby jego prace ukazały się po tekstach

W większości nauk społecznych, bardzo trudno jest poszerzyć ich wyjściowe działanie na inne typy materiałów, jak dokumenty, pisma, wykresy, kartoteki, zszywki, mapy, narzędzia organizujące, krótko mówiąc na technologie intelektualne". B. Latour Splatając na nowo to, co społeczne, s. 108.

B. Latour, S. Woolgar Życie laboratoryjne, s. 307, 331. Foucault w Narodzinach kliniki pisze, że akt poznania medycznego określa "systematyczne krzyżowanie się wielu serii informacji jednorodnych, lecz obcych sobie nawzajem - wielu serii, które obejmują nieskończoną liczbę odrębnych zdarzeń, a których przecinanie się pozwala ukazać się faktowi jednostkowemu w dającej się wyodrębnić jednostkowości" (s. 50).

M. Foucault What is critique?, w: tegoż The politics of truth, ed. S. Lotringer, transl. L. Hochroth, C. Porter, Semiotext(e), Los Angeles 2007, s. 59.

M. Foucault Słowa i rzeczy, s. 124.

59 Zob. M. Bal Quoting Caravaggio. Contemporary art, preposterous history, The University of Chicago Press, Chicago-London 1999. 
Latoura. Czytany w ten sposób, Foucault nie wydaje się w żadnej mierze anachroniczny. W niniejszym artykule zdajemy krótko sprawę z naszych zapożyczeń, użytków i odczytań obu tych autorów, próbując przy okazji pokazać wątki wspólne. Chcąc dochować wierności teorii aktora-sieci, w naszym projekcie próbowaliśmy podążać za ludzkimi (i nie-ludzkimi) aktorami, śledzić pozostawione przez nich ślady i "gęsto" opisywać zachodzące między nimi relacje. Zaczęliśmy jednak się zastanawiać, czy traktując laboratorium humanistyczne jako modus poznania, nie sprzeniewierzamy się Latourowskiej etnografii. Prace Latoura nie pozwalały nam na uhistorycznienie fenomenu laboratorium humanistycznego, nie dawały też prostej odpowiedzi, czy i jak odróżniać laboratorium humanistyczne od jego odpowiednika przyrodniczego. Dlatego odnaleźliśmy sojusznika w Foucaulcie i jego archeologii umożliwiającej wgląd nie tylko w to, co na powierzchni, lecz także w to, co kryje się głębiej ${ }^{60}$. Kiedy zaczęliśmy śledzić relacje między Foucaultem a Latourem, odkryliśmy, że między archeologią a etnografią laboratorium istnieją liczne powiązania i nawiązania ${ }^{61}$.

Foucault, pisząc Stowa i rzeczy, miał świadomość tego, że „antropologizacja” wiedzy stanowi dla niej zagrożenie, a „«nauki humanistyczne» są niebezpiecznym pośrednikiem w przestrzeni wiedzy" ${ }^{\prime 2}$. Podjęte przez Latoura i innych etnografów laboratorium studia nad nauką z jednej strony można postrzegać jako kontynuację Foucaultowskiego projektu, jego rozciągnięcie na nauki przyrodnicze, z drugiej zaś doprowadziły one do tego, czego obawiał się Foucault - podkopały fundamenty, na jakich opiera się wiedza, powodując podważenie ich autorytetu. $\mathrm{Na}$ ataki za relatywizację prawdy naukowej Latour odpowiada w przedmowie do polskiego wydania Życia laboratoryjnego, równo czterdzieści lat późniejszego od oryginału. Jego autorzy w obronie przed tym ciągle wysuwanym zarzutem uciekli się do myśli Gilles'a Deleuze'a: „relatywizm nie oznacza relatywności prawdy, lecz prawdę relacji”ø3. Kwestia prawdziwości wiedzy nabiera współcześnie, kiedy nauka staje się

60 Pamiętając o tym, że sam Foucault przestrzegał, by archeologii nie kojarzyć z wykopaliskami. Zob. M. Foucault Archeologia wiedzy, przeł. A. Siemek, PIW, Warszawa 1977, s. 167.

61 Andrzej W. Nowak zauważa, że szczegółowe analizy historyczne Foucaulta przypominają studia etnograficzne z zakresu STS, a jego propozycję można traktować jako przykład "metafizyki empirycznej", tegoż Wyobraźnia ontologiczna. Filozoficzna (re)konstrukcja fronetycznych nauk społecznych, Wydawnictwo IBL PAN, Warszawa 2016, s. 40.

M. Foucault Słowa i rzeczy, s. 313. 
przedmiotem ataków ze strony różnego rodzaju rewizjonistów, nowego znaczenia i wagi. Krytyczne i paralelne czytanie Foucaulta i Latoura sprzyja przekroczeniu radykalnego konstruktywizmu społecznego ku np. nowym formom realizmu.

Splot Latourowskiej etnografii laboratorium z Foucaultowską archeologią wiedzy objawia się w naszym projekcie na poziomie kilku rudymentarnych założeń; należą do nich: (1) idiograficzność i wyczulenie na konkret (opisowy charakter pracy); (2) archeologiczność rozumiana zarówno jako chęć sięgnięcia poza zarysowane dla humanistycznych laboratoriów cezury, jak i jako odrzucenie wizji połączenia badanych przypadków w spójną linię rozwojową; (3) zaakcentowanie sprawczej roli czynników pozaludzkich w procesach poznawczych; (4) próba usytuowania laboratoryjnego modusu poznania między poziomem instytucjonalnym (praktykami, projektami, organizacjami, przestrzeniami, narzędziami) a poziomem trudniej uświadamianego pola epistemologicznego.

Latourowska wizja laboratorium - oprócz dającego się przecież dość łatwo zaakceptować przez humanistę "grafocentryzmu" - wydaje się sprowadzać przede wszystkim do figury dźwigni - metafory oznaczającej możliwość dokonania zmiany, podminowania zastanego porządku i przemieszczenia własnych rezultatów poznawczych poza mury laboratorium. Co ciekawe, u Foucaulta znajdujemy inny przykład prostej maszyny: „transcendentalny kołowrotek", który wprawia nauki humanistyczne w ruch (chociaż to inwencja polskiego tłumacza, w oryginale mowa jest po prostu o „mobilności”). Kołowrotek oznacza samozwrotną dyspozycję humanistyki, jej skłonność do obierania samej siebie (i własnych warunków możliwości) jako przedmiotu poznania. Laboratorium humanistyczne może dysponować zarówno dźwignią (co niektórym wydaje się szczególnie potrzebne ${ }^{64}$ ), jak i kołowrotkiem dającym mu moc samopodważania. Zwrot laboratoryjny dokonujący się współcześnie w humanistyce może być świadectwem redystrybucji w polu ontoepistemologicznym, jak można by je określić, splatając ze sobą Foucaulta z Latourem.

64 Zob. A.W. Nowak Wyobraźnia ontologiczna. 


\section{Abstract}

\section{Aleksandra Kil, Jacek Małczyński, Dorota Wolska}

UNIVERSITY OF WROCŁAW

Reconnecting Latour with Foucault: From the Ethnography to the Archeology of the Humanities Laboratory

This article is a methodological assessment of the studies performed as part of the project "Laboratorium humanistyczne jako modus poznania" [The Humanities Laboratory as a Mode of Knowing]. Ethnographical studies of the laboratory by Bruno Latour and others are juxtaposed with Michel Foucault's archeological approach and the authors highlight links between the two. Although the ethnography of the laboratory makes it possible to draw attention to the still underrated significance of infrastructure in the production of knowledge in the humanities, this approach mostly focuses on exploring naturalist laboratories, thus making it impossible to define the identity of the humanities laboratory. The perspective of the archeology of knowledge allows us to peek into the still unacknowledged history of the humanities laboratories and it sets into motion the transcendental reel - a precondition for the hipoepistemic perspective and for becoming aware of what is on the surface of knowledge as well as of what is underneath.

\section{Keywords}

humanities laboratory, modus of knowing, ethnography of the laboratory, archeology of the humanities, Bruno Latour, Michel Foucault 